DOI: http://doi.org/10.21698/simi.2018.fp35

\title{
THE INDEXES IN ESTIMATING RAINFALL EROSIVITY - CASE STUDY BUCHAREST
}

$\underline{\text { Marin Rusanescu}^{1}}$, Ion Durbaca ${ }^{2}$, Elena Valentina Stoian ${ }^{3}$

${ }^{1}$ Valplast Industrie Bucharest, 9 Preciziei, Bucharest, marinrusanescu@gmail.com, Romania

${ }^{2}$ Polytechnic University Bucharest, Faculty of Mechanical Engineering, 313 Splaiul Independentei, district 6, 060042 Bucharest, Romania

${ }^{3}$ Valahia University of Targoviste, Faculty of Materials Engineering and Mechanics, Department of Materials Engineering, Mechatronics and Robotics, 13 Aleea Sinaia, Targoviste, Romania

\begin{abstract}
The objective of this study was to investigate the spatial and temporal distribution of annual precipitation erosivity in Bucharest (Romania). The analyzed period was 2009-2016, 1961-1990, using the indices: Fournier (IF), Fournier Modified (IFM), adapted to pluviometric recordings obtained from the meteorological station at the Polytechnic University of Bucharest, Faculty of Biotechnical Systems Engineering. Given the abundant rainfall in the summer months with implications for the soil, it is important to know the mathematical equations that can be quickly applied to assess soil erosion. The indices Fournier and Fournier modified obtained fall largely under the moderate aggressiveness class, but there have been years when the precipitation aggressiveness was moderate (2012, 2014). Erosion calculated according to Silva and Rufino is low throughout the analyzed period. This knowledge is very important to avoid the negative effects of pluvial erosion on agricultural crops.
\end{abstract}

Keywords: erosivity index, Fournier indexes, Fournier modified index, rainfall aggressiveness

\section{Introduction}

The erosive concept of rainfall describes erosivity as an interaction between the kinetic energy of rain drops and the surface of the soil. This may lead to a greater or lesser degree of detachment and reduction in the transport of soil particles depending on the amount of energy and rainfall, taking into account the same soil type, the same topographical conditions, and soil coverage (Ene et al 2010, Radulescu 2008, Radulescu et al 2010, Radulescu et al 2011a, Radulescu et al 2011b).

On the one hand, various authors have found good relationships between the Fournier index and annual values of rainfall erosivity (Bertoni \& Lombardi Neto 1990, Oliveira \& Medina 1990, Oduro-Afriyie 1996). According to Bertoni \& Lombardi Neto (1990), the ideal condition is to compute a data set of at least 20year rainfall, but it is possible to determine the erosivity using 10-year rainfall 


\section{INTERNATIONAL SYMPOSIUM "THE ENVIRONMENT AND THE INDUSTRY", SIMI 2018, PROCEEDINGS BOOK}

records. Mannaerts \& Gabriels studied in 2000 rainfall erosivity for Cape Verde Islands by means of 7-year rainfall pluviometric records.

For Cape Verde Islands was calculated significant relations with exponential equation by considering storms greater than $9 \mathrm{~mm}$ (erosive storms) (Mannaerts \& Gabriels 2000). This study proposes two regression models for estimating precipitation erosiveness and identifying suitable models in Bucharest Romania, based on daily, monthly, and annual rainfall data of the weather station. The detailed objectives of this study can be summarized as follows: (a) to construct new models for the large scale estimation of the erosive factor in Bucharest; and (b) to analyze the spatial distribution of the daily, monthly and annual rainfall erosivity in Bucharest. Excessive precipitation amounts lead to intense erosion of soils, landslides, floods and floods (Balteanu 1984, Rusanescu \& Rusanescu 2013).

The climate and topography of the surrounding area of Bucharest are suitable for agriculture (Rusanescu 2014a).

\section{Materials and Methods}

In this paper, rainfall recorded by weather station at the Faculty of Biotechnical Systems Engineering from Polytechnic University of Bucharest is located at coordinates $44.438^{\circ} \mathrm{N}$ Latitude, $26.047^{\circ} \mathrm{E}$ Longitude and $76.6 \mathrm{~m}$ elevation.

AWS weather station model / EV has a range wireless transmission up to $300 \mathrm{~m}$ and integrated set of sensors, stanchion $1.77 \mathrm{~m}$ and related tripod. It is equipped with sensors for acquisition of meteorological parameters: temperature, pressure, relative humidity, wind direction and speed, precipitation, solar radiation intensity (Rusanescu \& Rusanescu 2013). Data is transmitted every hour throughout the day at the site. The system enables instant viewing of measurements of meteorological parameters mentioned (Weather station Technical Paper 2009).

The maximum intensity of rainfall measurable: $0-300 \mathrm{~mm} / \mathrm{h}$.

The evaluation of pluvial aggression on the substrate was determined using the following indices: Fournier Index (IF), Fournier Modified Index (IFM) and Angot Index. These indices can be used to assess soil susceptibility to erosion, to calculate the erodibility of land and soil losses, to assess sloping land sensitivity due to intense precipitation (Scrinzi et al 2006, Sfiru et al 2011).

Interpretation of erosive classes determined by the Fournier index (Sfiru et al 2011, Alexandre Marco da Silva 2004) is follow:

The classes of rainfall erosion based on IF are: 0-20 mm very low erosion; 20-40 $\mathrm{mm}$ low erosion; 40-60 mm moderate erosion; 60-80 mm severe erosion; 80-100 mm very severe erosion; > 100 mm extremely severe erosion (Oduro-Afriyie 1996), (Alexandre Marco da Silva 2004). According to Rusanescu et al (2014b), classes of rainfall erosion based on MFI are: 0-60 very low; 60 - 90 mm low; 90-120 mm moderate; 120-160 mm high; > $160 \mathrm{~mm}$ very high. Pluviometric records were obtained from the meteorological station at the Polytechnic University of Bucharest, Faculty of Biotechnical Systems Engineering, Romania (Rusanescu 2016b). Data recording was for periods 2009-2016, 1960-1990. 


\section{INTERNATIONAL SYMPOSIUM "THE ENVIRONMENT AND THE INDUSTRY", SIMI 2018, PROCEEDINGS BOOK}

\section{Fournier Index}

Estimation of pluviometric erosion using the Fournier index (IF). The Fournier (IF) index is calculated based on the rainfall in the rainy month of the year, and the annual rainfall thus expressing rainfall (Rusanescu et al 2018, Rusanescu et al 2016a).

$$
I F=\frac{P_{m}^{2}}{P}
$$

where: IF - Fournier Index, $\mathrm{P}_{\mathrm{m}}$ - rainfall in $\mathrm{m}$ month of the most rainy year in year (mm), P - annual rainfall (mm).

Fournier Modified Index (MFI)

The Fournier Modified Index (IFM) is determined with equation (2):

$$
I F M=\sum_{1}^{12} \frac{p_{i}^{2}}{P}
$$

where: $\mathrm{p}_{\mathrm{i}}$ - the average rainfall for the month i (mm), $\mathrm{P}$ - the average annual rainfall and IFM - the modified Fournier index (Scrinzi et al 2006, Rusanescu 2014a).

\section{Results and Discussion}

The Fournier rainfall aggressive classes were calculated based on the amount of precipitation recorded by the weather station at the Faculty of Engineering of Biotechnical Systems Polytechnic University of Bucharest (2009-2016, 1960-1990). The annual values of the Fournier (IF) index calculated for Bucharest during the period 2009-2016, 1960-1990, reach values below $60 \mathrm{~mm}$ in the years: 2009, 2010, 2011, 2013, 2014, 2016 low rainfall aggressiveness. In 2015, 1960-1990 rainfall aggressiveness is very low. In 2012 (64.9 mm), characterized by a severe rainfall aggression, due to the conditions of the plain relief, the low degree of coverage with forest vegetation, the problems related to wilting, soil washing and erosion in the surface may increase. The soils in the area near Polytechnic University of Bucharest are in a very low or low rainfall erosion class in most of the analyzed years, except in 2012 when severe pluvial erosion was used using the scale of Oduro-Afriyie 1996.

The pluvial aggression classes based on IF calculated for Bucharest 2009-2016, 1961-1990 are as follows: in order the year followed by IF (mm): 2009 with $31 \mathrm{~mm}$; 2010 with $20.1 \mathrm{~mm}$; 2011 with 37.2 mm; 2012 with $64.8 \mathrm{~mm}$; 2013 with $11.0 \mathrm{~mm}$; 2014 with 24.6 mm; 2015 with 14.2 mm; 2016 with 22.3 mm; 2009-2016 with 16.7 mm; 1961-1990 with $10 \mathrm{~mm}$. 


\section{INTERNATIONAL SYMPOSIUM "THE ENVIRONMENT AND THE INDUSTRY", SIMI 2018, PROCEEDINGS BOOK}

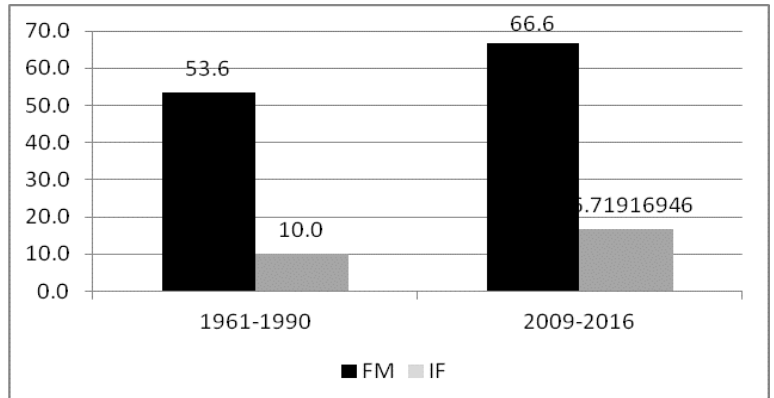

Figure 1. Values obtained for the Fournier and Fournier index for Bucharest 20092016.

Classes of flood erosion by MFI for Bucharest ranges 2009-2016 and 1961-1990 are as follows: for the years 1961-1990 with $53.6 \mathrm{~mm}$; $2009-2016$ with $66.6 \mathrm{~mm}$; 2009 with $78.7 \mathrm{~mm}$; 2010 with 75.0 mm; 2011 with 77.4 mm; 2012 with $96.6 \mathrm{~mm}$; 2013 with $77.7 \mathrm{~mm}$; 2014 with 105.6 mm; 2015 with $73.8 \mathrm{~mm}$ and 2016 with 87.9 $\mathrm{mm}$.

In Bucharest the average values of this index range are from $53.6 \mathrm{~mm}$ to $105.9 \mathrm{~mm}$. According to the pluvial aggressive classes, MFI for Bucharest results in a low aggressiveness for the years: 2009, 2010, 2011, 2013, 2015, 2016, 1961-1990. For the years 2012 and 2014, there is a moderate aggressiveness.

The triggering of geomorphologic erosion processes may have as a determining factor either a long duration of precipitation or a high intensity of precipitation, which leads to the accumulation of a large volume of water, which flows on the slopes in the form of sludge, favoring the production of the processes Irritation and torrentiality.

Thus, as a result of the analysis of the IF and MFIs calculated for the period 20092016, it is concluded that the soils in Bucharest are subject to a low, very low and moderate rain aggressive risk, being classified as rainwater aggressive classes 1 and 2, but also to a risk of moderate pluvial aggressiveness depending on the morphodynamic characteristics of the analyzed area and the duration and intensity of precipitations falling within the time interval to be analyzed.

The annual distribution of the maximum amount of precipitation in 24 hours is not uniform (Rusanescu et al 2010). Multiannual monthly distribution shows a continuous rise in rainfall from January to June when it reaches the maximum (197.4 mm in June 2012) and then decreases until February to a minimum (0.3 mm in December 2013). In the cold season, due to low thermal convection and the prevalence of anticyclonic circulation, the maximum amount of rainfall in 24 hours is smaller and slightly erosive compared to summer precipitation. This is due to the substrate and soil resistance due to low temperature. There are exceptions in the cold season when the monthly averages are exceeded (in Bucharest, the maximum of 


\section{INTERNATIONAL SYMPOSIUM "THE ENVIRONMENT AND THE INDUSTRY", SIMI 2018, PROCEEDINGS BOOK}

February was $84.8 \mathrm{~mm}$ on February 10, 2010, and the maximum of $152.9 \mathrm{~mm}$ took place on December 17, 2014). These exceptions in the cold season are due to exceptional synoptic situations, meaning the adhesion of moisture-loaded air masses.

Research conducted by the Pedological and Agrochemical Research Institute shows that the pluvial aggression in Romania has the following characteristics: it is smaller in the Western part of the country (0.08), moderate in the Southern (0.13), Eastern and Northeast (0.10) and high in the Center of the country, the Sub-Carpathian hills (0.14), the Transylvania Plateau (0.12) and the Carpathians (0.15 - 0.16) (Costea 2012). Most torrential rains occur in the summer, especially in June and July.

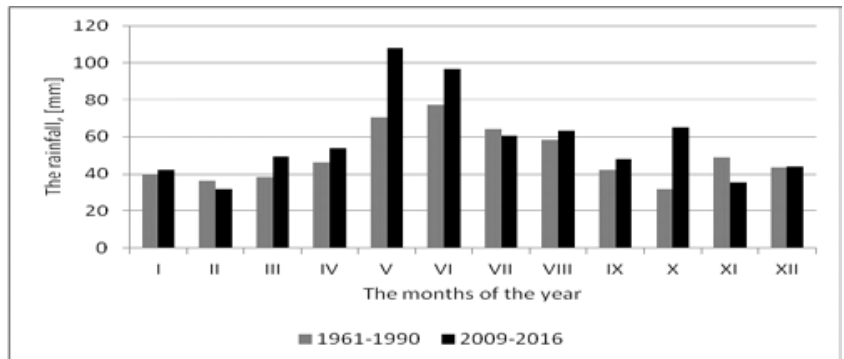

Figure 2. Precipitation recorded in Bucharest during 2009-2016, 1961-1990.

The equations used to determine the monthly / annual values of erosivity according to the surface of the territory and their authors. Equation (3), according to Rufino et al 1993 is a linear model; Equation (4) according to Silva (2001) is based on Fournier's model:

$$
\begin{aligned}
& R_{x}=19.55+\left(4.20 \cdot M_{x}\right) \\
& R_{x}=42.307 \cdot\left(\frac{M_{x}^{2}}{P}\right)+69.763
\end{aligned}
$$

where $R_{x}$ is the factor $R\left(M J\right.$ mm ha ${ }^{-1} h^{-1}$ year ${ }^{-1}$ ) for the month $x, M_{x}$ is the average depth of the monthly precipitation $(\mathrm{mm})$ and $\mathrm{P}$ is the average annual precipitation (mm) (Silva 2001). Class for interpretation of annual erosivity index (R) where erosivity (MJ mm year ${ }^{-1} \mathrm{ha}^{-1} \mathrm{~h}^{-1}$ ) are as follows: $\mathrm{R} \leq 2452$ low erosivity; $2452<$ $\mathrm{R} \leq 4905$ medium erosivity; $4905<\mathrm{R} \leq 7357$ medium-strong erosivity; $7357<\mathrm{R} \leq$ 9810 strong erosivity; $\mathrm{R}>9810$ very strong erosivity.

It is noticed that the erosivity is low throughout the analyzed period. Erosion calculated for the same period according to Silva 2001 is low. 
Table 3. Erosivity calculated according to Rufino et al 1993 according to the rainfall recorded in Bucharest during the period 2009-2016, 1961-1990

\begin{tabular}{|c|c|c|c|c|c|c|c|c|c|c|c|c|}
\hline 号 & ル & $\Xi$ & 目 & $\geq$ & $>$ & 5 & $\overline{7}$ & $\bar{B}$ & $\underset{\boldsymbol{u}}{\not}$ & $x$ & $\bar{x}$ & $\bar{x}$ \\
\hline 竎 & $\begin{array}{l}9 \\
\stackrel{9}{0} \\
\infty \\
\infty\end{array}$ & $\stackrel{0}{\stackrel{\theta}{-}}$ & $\begin{array}{l}0 \\
\stackrel{8}{\infty} \\
\stackrel{-1}{1}\end{array}$ & $\begin{array}{l}\infty \\
\stackrel{\sim}{J}\end{array}$ & $\stackrel{\vec{J}}{\stackrel{+}{m}}$ & $\begin{array}{l}0 \\
\dot{f}\end{array}$ & $\begin{array}{l}\mathscr{D} \\
\stackrel{D}{\sim}\end{array}$ & $\begin{array}{l}\dot{\nabla} \\
\stackrel{d}{0}\end{array}$ & $\begin{array}{l}\infty \\
\stackrel{\mathscr{S}}{\longrightarrow}\end{array}$ & ลิ่ & $\stackrel{\stackrel{\sim}{\sim}}{\underset{\sim}{N}}$ & $\stackrel{+}{\stackrel{\nabla}{े}}$ \\
\hline 客 & 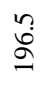 & $\begin{array}{l}m \\
\stackrel{\leftrightarrow}{0}\end{array}$ & $\begin{array}{l}\circ \\
\stackrel{0}{\sim} \\
\text { N }\end{array}$ & 守 & $\stackrel{\nabla}{\stackrel{\nabla}{\sigma}}$ & 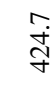 & $\stackrel{\text { ำ }}{\stackrel{\text { }}{N}}$ & $\stackrel{\stackrel{\llcorner}{+}}{\underset{\sim}{N}}$ & 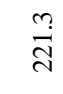 & $\begin{array}{l}\dot{0} \\
\dot{D}\end{array}$ & ִֻ & $\stackrel{+}{\stackrel{+}{+}}$ \\
\hline 옹 & $\stackrel{へ}{0}$ & $\stackrel{\infty}{\stackrel{\infty}{\Omega}}$ & $\stackrel{0}{\stackrel{0}{~}}$ & ச் & ○्. & $\begin{array}{l}\stackrel{0}{\text { }} \\
\text { Fे }\end{array}$ & $\begin{array}{l}\text { กี } \\
\text { ปู }\end{array}$ & $\begin{array}{l}\text { Na } \\
\stackrel{0}{m} \\
m\end{array}$ & 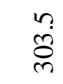 & $\underset{\stackrel{N}{\sim}}{\stackrel{\sim}{N}}$ & ָָ & $\vec{\vartheta}$ \\
\hline 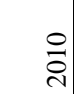 & 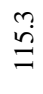 & ले & $\begin{array}{l}\infty \\
\ddot{n} \\
\stackrel{N}{ }\end{array}$ & $\stackrel{\text { 뭉 }}{\stackrel{+}{\sim}}$ & $\frac{9}{\text { กิ }}$ & $\begin{array}{l}\mathscr{P} \\
\stackrel{7}{7}\end{array}$ & 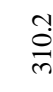 & $\begin{array}{l}0 \\
\stackrel{\text { I }}{-}\end{array}$ & $\begin{array}{l}\circ \\
\stackrel{\circ}{0} \\
\stackrel{0}{-1}\end{array}$ & 롱 & 웅 & 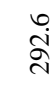 \\
\hline$\stackrel{\overrightarrow{-}}{\vec{\nu}}$ & $\stackrel{+}{\dot{\sigma}}$ & $\stackrel{0}{r}$ & $\stackrel{\mathscr{\rho}}{\stackrel{\nabla}{ }}$ & 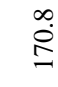 & $\begin{array}{l}0 \\
\dot{\mathscr{S}} \\
\stackrel{1}{0}\end{array}$ & 芦 & $\frac{\sim}{m}$ & $\stackrel{\stackrel{N}{\sim}}{\stackrel{\sim}{N}}$ & $\begin{array}{l}\mathscr{\sigma} \\
\stackrel{\sigma}{\sigma}\end{array}$ & 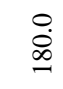 & mె. & 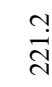 \\
\hline 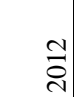 & ڤ్ & ஜேं & 옷 & $\stackrel{\stackrel{N}{\sim}}{\stackrel{J}{\sim}}$ & $\begin{array}{l}0 \\
\stackrel{\infty}{+} \\
\stackrel{+}{\infty}\end{array}$ & $\stackrel{0}{\stackrel{1}{\wedge}}$ & 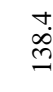 & 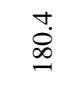 & $\begin{array}{l}\text { の } \\
\infty \\
\stackrel{9}{\rightarrow}\end{array}$ & $\begin{array}{l}\text { ָे } \\
\stackrel{\sim}{\sim}\end{array}$ & $\begin{array}{l}\infty \\
\text { vi }\end{array}$ & $\begin{array}{l}\stackrel{\circ}{\vec{m}} \\
\stackrel{m}{7}\end{array}$ \\
\hline$\stackrel{m}{\circ}$ & $\stackrel{0}{\stackrel{0}{-}}$ & $\stackrel{+}{\stackrel{\nabla}{N}}$ & $\begin{array}{l}0 \\
\text { Ñ } \\
\text { Nิ }\end{array}$ & 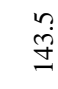 & 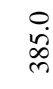 & 号 & $\stackrel{\sim}{\stackrel{N}{\sim}}$ & $\stackrel{\varphi}{\stackrel{0}{\text { N }}}$ & $\stackrel{+}{\dot{m}}$ & 范 & $\begin{array}{l}\circ \\
\mathscr{D} \\
\stackrel{1}{-1}\end{array}$ & $\stackrel{\infty}{\stackrel{\sim}{\sim}}$ \\
\hline$\underset{⿱}{\stackrel{D}{*}}$ & 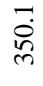 & $\stackrel{\sim}{\sim}$ & ָ̃ & $\stackrel{\text { V }}{\stackrel{+}{+}}$ & 㑒 & ชี & $\begin{array}{l}\text { } \\
\text { ָे } \\
\text { ָे }\end{array}$ & 它 & $\begin{array}{l}\mathscr{0} \\
\stackrel{\infty}{\vec{\nu}} \\
\stackrel{\sim}{v}\end{array}$ & $\begin{array}{l}\text { @़ } \\
\text { ஓे }\end{array}$ & 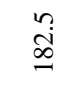 & जे. \\
\hline 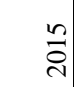 & $\begin{array}{l}\text { L } \\
\stackrel{0}{\circ} \\
\stackrel{10}{-1}\end{array}$ & $\begin{array}{l}\infty \\
\stackrel{\infty}{\infty} \\
\stackrel{\infty}{-1}\end{array}$ & ஜேं & $\stackrel{\sim}{\stackrel{\sim}{\sim}}$ & $\stackrel{+}{\stackrel{\Delta}{N}}$ & $\stackrel{0}{\stackrel{0}{\Delta}}$ & $\stackrel{0}{\stackrel{0}{\Delta}}$ & $\begin{array}{l}n \\
\infty \\
\infty \\
\infty \\
m\end{array}$ & 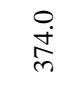 & $\stackrel{\infty}{\stackrel{\infty}{N}}$ & $\begin{array}{r}\hat{g} \\
\dot{y}\end{array}$ & ลุ \\
\hline $\begin{array}{l}0 \\
\stackrel{0}{0} \\
\text { N }\end{array}$ & $\begin{array}{l}\stackrel{n}{\sigma} \\
\dot{n}\end{array}$ & $\begin{array}{l}\stackrel{\sim}{0} \\
\infty \\
\infty\end{array}$ & 芦 & $\begin{array}{l}\text { م) } \\
\text { సे }\end{array}$ & 亩 & $\stackrel{\circ}{\stackrel{8}{+}}$ & $\begin{array}{l}\infty \\
\emptyset \\
\infty\end{array}$ & & $\begin{array}{l}0 \\
\dot{\theta} \\
\stackrel{0}{-1}\end{array}$ & $\begin{array}{l}\text { ỹ } \\
\text { ஸे }\end{array}$ & 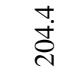 & $\stackrel{\circ}{\circ}$ \\
\hline
\end{tabular}


Table 4. Erosion calculated according to Silva 2001 depending on rainfall recorded in Bucharest during 2009-2016, 1961-1990

\begin{tabular}{|c|c|c|c|c|c|c|c|c|c|c|c|c|}
\hline 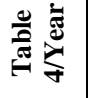 & - & $=$ & $\Xi$ & $\geq$ & $>$ & 5 & $\xi$ & $\Xi$ & $凶$ & $\rtimes$ & $\bar{x}$ & $\overline{\bar{x}}$ \\
\hline $\begin{array}{l}\dot{1} \\
\stackrel{g}{g}\end{array}$ & $\stackrel{0}{\stackrel{\infty}{0}}$ & 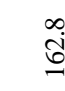 & $\stackrel{M}{\mathcal{N}}$ & 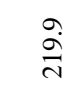 & 욤 & $\begin{array}{l}\text { \&े } \\
\text { \& }\end{array}$ & त्ठ & $\stackrel{\circ}{\stackrel{\vec{m}}{m}}$ & $\ddot{\mathscr{\phi}}$ & $\stackrel{\neg}{\vec{\forall}}$ & $\begin{array}{l}\infty \\
\infty \\
\infty \\
\sim \\
\sim\end{array}$ & 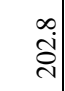 \\
\hline 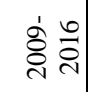 & $\stackrel{M}{\stackrel{M}{-}}$ & $\overrightarrow{\widetilde{I}}$ & $\begin{array}{l}\sigma \\
\infty \\
\stackrel{\sim}{N}\end{array}$ & $\stackrel{m}{\stackrel{\leftrightarrow}{\sim}}$ & $\stackrel{\overbrace{}}{\stackrel{1}{*}}$ & 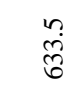 & $\stackrel{\sim}{\stackrel{N}{N}}$ & $\begin{array}{l}\infty \\
\stackrel{\dot{m}}{m}\end{array}$ & 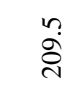 & 今ે & 字 & $\begin{array}{c}0 \\
\dot{0} \\
\infty \\
-1\end{array}$ \\
\hline$\stackrel{\text { ¿े }}{\stackrel{\sim}{े}}$ & $\stackrel{\text { 눈 }}{\underset{-}{-}}$ & 올 & 今ે & $\stackrel{9}{\stackrel{9}{\infty}}$ & $\begin{array}{l}\stackrel{+}{\circ} \\
\stackrel{\leftrightarrow}{\Delta}\end{array}$ & 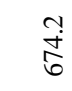 & $\stackrel{\mathscr{m}}{\stackrel{\mathscr{m}}{\rightarrow}}$ & 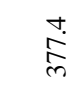 & חై & $\stackrel{\overbrace{}}{\stackrel{\sim}{J}}$ & 菑 & 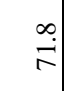 \\
\hline$\stackrel{\circ}{\stackrel{\sim}{\sim}}$ & $\stackrel{0}{\circ}$ & $\begin{array}{l}\text { ᄂn } \\
\text { }\end{array}$ & $\underset{\stackrel{ \pm}{N}}{\stackrel{+}{N}}$ & ब্ं & 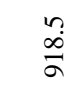 & ஷั่ & 总 & 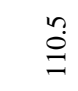 & هี & $\begin{array}{l}\stackrel{n}{\circ} \\
\stackrel{\mathrm{f}}{\mathrm{m}}\end{array}$ & $\overrightarrow{\tilde{\sigma}}$ & 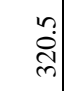 \\
\hline $\overrightarrow{\text { s. }}$ & $\stackrel{\infty}{\text { g. }}$ & 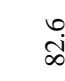 & $\stackrel{0}{i}$ & $\stackrel{\hat{~}}{\hat{A}}$ & $\stackrel{7}{6}$ & $\begin{array}{l}\text { mà } \\
\text { षें }\end{array}$ & $\begin{array}{l}\text { 엄 } \\
\text { ஸे }\end{array}$ & 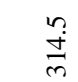 & $\begin{array}{l}\infty \\
\dot{0} \\
\dot{0}\end{array}$ & क़े & 苍 & 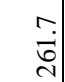 \\
\hline : & 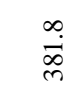 & $\begin{array}{l}0 \\
\ddot{\infty}\end{array}$ & $\underset{\infty}{\stackrel{\circ}{i}}$ & ‡্ঠ & $\overrightarrow{\vec{q}}$ & సֶ. & 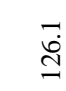 & $\stackrel{ }{\stackrel{P}{~}}$ & $\begin{array}{l}\circ \\
\stackrel{\circ}{\circ} \\
\stackrel{\leftrightarrow}{\sigma}\end{array}$ & 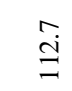 & $\stackrel{\stackrel{N}{~}}{\wedge}$ & 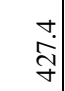 \\
\hline $\begin{array}{l}m \\
\stackrel{\sim}{\sim}\end{array}$ & $\stackrel{\hat{D}}{\stackrel{N}{N}}$ & $\vec{\nabla}$ & $\begin{array}{l}\stackrel{+}{0} \\
\vec{m}\end{array}$ & $\stackrel{0}{\overrightarrow{\mathrm{I}}}$ & 色 & ஜ욤 & $\begin{array}{l}\stackrel{9}{\omega} \\
\stackrel{\omega}{\sigma}\end{array}$ & $\stackrel{\hat{\alpha}}{\stackrel{N}{N}}$ & $\begin{array}{l}0 \\
\dot{D} \\
\dot{D}\end{array}$ & $\stackrel{\vec{\Im}}{\stackrel{7}{\vartheta}}$ & 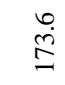 & $\begin{array}{l}\infty \\
\ddot{0} \\
\ddot{0}\end{array}$ \\
\hline $\begin{array}{l}\vec{\Delta} \\
\stackrel{\Delta}{N}\end{array}$ & $\hat{f}$ & هి. & 㤐 & $\begin{array}{l}0 \\
\dot{\delta} \\
\dot{\delta}\end{array}$ & 仓ें & $\stackrel{8}{\circ}$ & $\stackrel{n}{\stackrel{n}{\sim}}$ & 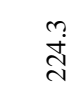 & $\begin{array}{l}\text { مִ } \\
\stackrel{0}{0}\end{array}$ & 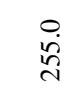 & $\begin{array}{l}0 \\
\dot{m} \\
\tilde{n}\end{array}$ & $\stackrel{\circ}{=}$ \\
\hline$\stackrel{n}{\stackrel{n}{\tilde{n}}}$ & $\stackrel{m}{m}$ & 㟔 & 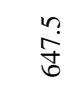 & $\begin{array}{l}\stackrel{0}{\vec{J}} \\
\stackrel{\sim}{N}\end{array}$ & $\begin{array}{l}\infty \\
\stackrel{\infty}{d} \\
\stackrel{\sim}{N}\end{array}$ & $\stackrel{\sim}{\stackrel{\infty}{\sim}} \underset{\sim}{\sim}$ & 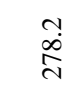 & $\begin{array}{l}0 \\
\dot{\theta} \\
\dot{1}\end{array}$ & 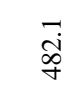 & @i & $\begin{array}{l}\text { L } \\
0 \\
0 \\
0\end{array}$ & $\stackrel{\circ}{\circ}$ \\
\hline $\begin{array}{l}0 \\
\stackrel{0}{5} \\
\stackrel{N}{N}\end{array}$ & $\stackrel{+}{\infty}$ & $\stackrel{\circ}{\sigma}$ & $\begin{array}{l}\infty \\
\infty \\
\infty \\
\infty\end{array}$ & $\begin{array}{l}\text { ․ } \\
\text { مे }\end{array}$ & $\begin{array}{l}\circ \\
\stackrel{0}{0} \\
\text { in }\end{array}$ & $\begin{array}{l}\stackrel{\sim}{\oplus} \\
\underset{\infty}{\infty}\end{array}$ & $\overrightarrow{\dot{D}}$ & ڤ્ळ & 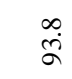 & $\stackrel{20}{0}$ & 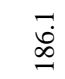 & $\widehat{N}$ \\
\hline
\end{tabular}




\section{INTERNATIONAL SYMPOSIUM "THE ENVIRONMENT AND THE INDUSTRY", SIMI 2018, PROCEEDINGS BOOK}

\section{Conclusions}

Applying Fournier indices to assess aggressiveness of precipitation is a simple, rapid method. The two indices are influenced by the pluviometric characteristics, thus the monthly and annual values recorded at the representative stations for Bucharest, which give them their local or regional character.

Both variants of the Fournier indices indicate the same classes of pluvial aggression. The modified Fournier Index is more relevant to the study of aggressiveness of precipitation because it takes into account the value of precipitation in different months of the year and the variation over a given year. The indices obtained fall largely under the moderate aggressiveness class, but there have been years when the precipitation aggressiveness was moderate (2012, 2014).

From the analysis of the indices of pluvial aggression assessment on the substrate, periodically, favorable conditions of occurrence and manifestation of the pluvial erosion processes are created, their effect being stronger when they intervene after a prolonged drought period, especially in the periods of march - April, July and august, or in some cases from October to November. For the years 2013 and 2014, the high values of over $2-2.5$ and even 3 at some stations indicate the creation of favorable conditions for triggering of slope and linear erosion processes. Erosion calculated according to Silva 2001 and Rufino 1993 is low throughout the analyzed period.

\section{References}

Alexandre Marco DA Silva 2004, 'Rainfall erosivity map for Brazil', Catena, vol. 57, pp. 251-259.

Balteanu, D 1984, Relief Yesterday, Today, Meat, Albatros Publishing House, Bucharest, pp. 205.

Bertoni, J \& Lombardi Neto, F 1990, Conservação do solo I'cone, Editora, Sao Paulo, Brazil, pp. 355.

Costea, M 2012, 'Using the Fournier indexes in estimating rainfall erosivity. Case study - The Secasul Mare Basin`, Conference of air and water components of the environment, Babes-Bolyai University, Cluj-Napoca, pp. 313-320.

Mannaerts, CM \& Gabriels, D 2000, 'Rainfall erosivity in Cape Verde', Soil and Tillage Research, vol. 55, pp. 207-212.

Ene, A, Gheboianu, AI, Stihi, C, Radulescu, C 2010, 'Assessment of river water quality in central and eastern parts of Romania using atomic and optical methods', Journal of Science and Arts, Year 10, vol. 12, no. 1, pp. 113-118.

Oduro-Afriyie K 1996, 'Rainfall erosivity map for Ghana', Geoderma, vol. 74, pp.161-166.

Oliveira Júnior, RR \& Medina, BF 1990, 'A erosividade das chuvas em Manaus (AM) ', Revista Brasileira de Ciencia do Solo, vol. 14, pp. 235-239.

Radulescu, C 2008, 'Emisii poluante: Metode pentru reducerea acestora' in Romanian, Bibliotheca, Targoviste. In Romanian. 


\section{INTERNATIONAL SYMPOSIUM "THE ENVIRONMENT AND THE INDUSTRY", SIMI 2018, PROCEEDINGS BOOK}

Radulescu, C, Stihi, C, Popescu, IV, Busuioc, G, Gheboianu, AI, Cimpoca, GhV, Dulama, ID \& Diaconescu, M 2010, `Determination of heavy metals content in wild mushrooms and soil by EDXRF and FAAS techniques', Ovidius University Annals of Chemistry, vol. 21, no. 1, pp. 9-14.

Radulescu, C, Stihi, C, Cimpoca, GhV, Popescu, IV, Busuioc, G \& Gheboianu, AI 2011a, 'Evaluation of heavy metals content in edible mushrooms by microwave digestion and flame atomic absorption spectrometry', Scientific Study \& Research, vol. 12, no. 2, pp. 155.

Radulescu, C, Stihi, C, Popescu, IV, Nitescu, VO, Dulama, ID, Gheboianu, AI, Chilian, A, Bucurica, A \& Bancuta, R 2011b, 'Analysis of wastewater from ecological car wash - a case study', Journal of Science and Arts, Year 11, vol. 15, no. 2, pp. 193-200.

Rufino, RL, Biscaia, RCM \& Herten, GH 1993, 'Determinação do potencial erosivo da chuva do estado do Paraná', Revista Brasileira de Ciencia do Solo, vol. 17, pp. $439-444$.

Rusanescu, CO 2014a, 'Characterization of rainfall with rainfall indices in the city of Bucharest in (2009-2012)'; $3^{\text {rd }}$ International Conference of Thermal Equipment, Renewable Energy and Rural Development, pp. 307-310.

Rusanescu, CO 2014b, 'Rainfall indices in the city of Bucharest', Hidraulica, vol. 3, pp. 31-35.

Rusanescu, CO, Popescu, IN \& David, L 2010, 'Relative humidity monitoring', EG' vol. 10, pp. 175-180.

Rusanescu, CO, Rusanescu, M, Begea M, Paraschiv, G, Biris, SSt, Voicu, Gh \& Popescu, IN 2018, 'Assessing the risk of aridity: a case study Bucharest Romania', 46th International Symposium “Actual Tasks on Agricultural Engineering”, University of Zagreb, Faculty of Agriculture, Opatija, Croatia, pp. 45-56.

Rusanescu, CO, Paraschiv, G, Biris, SSt, Voicu, Gh \& Rusanescu, M 2016a, 'Characterization of Rainfall Regime in Bucharest (2009-2015)', Hidraulica, vol. 3, pp. 34-41.

Rusanescu, CO, Paraschiv, G, Biris, SSt, Voicu, G, Rusanescu, M \& Begea, M 2016b, 'Using the indexes in estimating rainfall erosivity - Case study Bucharest', International symposium agricultural and mechanical engineering, Bucharest, pp. 171-176.

Rusanescu, CO \& Rusanescu, M 2013, 'Some aspects regarding the global warming', Hidraulica, vol. 4, pp. 7-11.

Scrinzi, G, Gregori, E, Giannetti, F, Galvan, D, Zorn, G, Colle, G \& Andreanelli, MC 2006, 'Un modello di valutazione della funzionalità protettiva del bosco per la pianificayione forestale: la componente stabilità dei versanti rispetto ai fenomeni franosi superficiali', Forest (Review of Italian Society of Silviculture and Forest Ecology), vol. 3, no.1, pp. 98-155. In Italian.

Sfiru, R, Cirdei, P, Herea, V \& Ertekin, C 2011, 'Calculation of rainfall erosion intensity (rainfall erosivity) in Valea Calugareasca wine growing area', INMATEH - Agricultural Engineering, Bucuresti, vol. 34, no. 2, pp. 23 - 28. 
Silva, AM 2001, 'Ìndice de erosividade e sua relacao com a pluviometria e coeficiente de chuva em Juazeiro (BA)’, ESALQ, Piracicaba, Sao Paulo, Brazil.

Weather station Technical Paper 2009, Elettronica Veneta. 